\title{
Strategi Kelompok Bimbingan Ibadah haji (KBIH) Maqdis Dalam Meningkatkan Pelayanan Prima Terhadap Calon Jamaah Haji Tahun 2017
}

\author{
Nuning Octaviani ${ }^{1 *}$, Arif Rahman $1^{1}$, Herman $2^{2}$ \\ ${ }^{123}$ Jurusan Manajemen Dakwah, Fakultas Dakwah dan Komunikasi, UIN Sunan Gunung Djati, Bandung \\ *Email : nuning@gmail.com
}

\begin{abstract}
ABSTRAK
Tujuan dari penelitian ini untuk mengetahui strategi KBIH dalam meningkatkan pelayanan prima berupa kebutuhan pelanggan atau jamaah secara praktis maupun kebutuhan para pelanggan atau jamaah secara emosional dan proses dari pemberian pelayanan yang ada di KBIH Maqdis dalam hal meningkatkan pelayanan prima terhadap calon jamaah. Metode yang digunakan pada penelitian ini adalah metode deskriptif dengan menggunakan pendekatan kualitatif. Adapun langkah-langkah penelitian ditempuh dengan: penentuan lokasi penelitian, pengumpulan data dengan menggunakan tehnik observasi, wawancara, studi kepustakaan, dan dokumentasi selanjutnya analisis data dengan cara reduksi data kemudian klasifikasi data dan penarikan kesimpulan. Dari hasil penelitian dapat disimpulkan bahwa strategi KBIH Maqdis dalam Meningkatkan pelayanan prima cukup baik karena hal ini dapat dilihat dari kebutuhan secara praktis yang diberikan KBIH Maqdis kepada calon jamaah haji. Pihak KBIH Maqdis memberikan pelayanan yang baik dari segi pelayanannya pembimbing, pengurus maupun ketuanya. Karena dengan upaya memberikan pelayanan yang baik diharapkan jamaah haji merasa puas sehingga dapat memberitahu kepada orang lain tentang kualitas pelayanan yang diberikan pihak KBIH Maqdis terhadap jamaah. Proses pelaksanaan pemberian pelayanan pun dapat terlihat baik yakni dilihat dari pemberian pelayanan prima yang ada di KBIH Maqdis Kota Bandung.
\end{abstract}

Kata Kunci : Strategi; KBIH; Pelayanan Prima.

\section{ABSTRACT}

The purpose of this study is to determine the KBIH strategy in improving prime service in the form of customer needs or practical pilgrims as well as the needs of customers or pilgrims emotionally and the process of providing services in KBIH Maqdis in terms of improving excellent service for prospective pilgrims. The method used in this study is descriptive method using a 
qualitative approach. The research steps are taken by: determining the location of research, collecting data using observation techniques, interviews, literature studies, and documentation then analyzing data by means of data reduction then data classification and drawing conclusions. From the results of the study it can be concluded that the KBIH Maqdis strategy in improving excellent service is quite good because this can be seen from the practical needs given by KBIH Maqdis to prospective pilgrims. The KBIH Maqdis party provides good service in terms of its service, supervisor, management and chairman. Because the effort to provide good service is expected that pilgrims feel satisfied so that they can tell others about the quality of services provided by KBIH Maqdis to worshipers. The process of implementing service delivery can also look good, that is seen from the provision of excellent service in KBIH Maqdis, Bandung.

Keywords : Strategy; KBIH; Excellent service.

\section{PENDAHULUAN}

Haji merupakan salah satu dari lima pondasi agama islam, merupakan rukun kelima yang merupakan perwujudan taat seorang hamba kepada Allah yang paling agung. Mengingat dalam praktik antara ibadah haji dan umroh adalah sama. Baik dalam syarat maupun rukunnya, kecuali ada tiga yang beda yaitu mengenai waktu, wukuf di Arafah dan melontar jumroh.

Kewajiban untuk berhaji minimal sekali dalam seumur hidup, dibebankan hanya kepada seorang muslim yang mampu dalam arti luas yaitu mampu secara jasmani dan rohani. Selain itu, "mampu" berarti juga mampu secara finansial, dalam artian memiliki dana yang diperlukan untuk menjalankan ibadah haji yang dilaksanakan ditempat jauh. Sebab hal tersebut ibadah haji bisa dikatakan ibadah yang unik (unique). Tidak semata-mata bentuk ritualnya itu sendiri tetapi seperti dapat disarikan dari Encyclopedia van Nederlandsch Indie, pelaksanaan ibadah haji ini melibatkan unsur-unsur lain diluar aspek ritual agar pelaksanaannya dapat berjalan dengan baik, sehingga sseorang akan pulang dengan predikat haji mabrur.

Haji pada hakikatnya merupakan sarana dan media bagi umat islam untuk melaksanakan ibadah ke Baitullah dan tanah suci karena setiap tahunnya sebagian kaum muslimin dari seluruh dunia datang untuk menunaikan ibadah haji. Beberapa amal ibadah dengan syarat-syarat tertentu. Haji diwajibkan atas orangorang yang mampu yang dilaksanakan sekali seumur hidupnya (Rasyid, 2002:35).

Seiring dengan itu bermunculan lembaga haji yang menanamkan dirinya dengan kelompok bimbingan ibadah haji (KBIH) yang didirikan bertujuan untuk membantu calon jamaah haji dalam melaksanakan ibadah haji agar mencapai kesempurnaan dan mencapai derajat yang sempurna yaitu haji yang mabrur.

$\mathrm{KBIH}$ sekarang ini dipandang dalam konteks manajemen adalah sebagai wadah atau organisasi dalam upaya mengelola jamaah untuk terus melakukan pembenahan dan perbaikan dalam memfasilitasi dalam upaya dakwah bil hal, dengan demikian KBIH bersifat orientasi sosial (social oriented). Kemudian yang 
sering terjadi agar KBIH dapat menambah jamaah dan mengejar predikat $\mathrm{KBIH}$ yang terbaik. Oleh karena itulah untuk mencapai predikat KBIH yang terbaik dibutuhkan sebuah strategi dibidang mengrekrut dan dibidang pelayanan calon jamaah haji.

Namun, untuk mencapai predikat yang terbaik itu tidak mudah untuk mewujudkannya, dimana suatu organisasi atau lembaga tersebut pasti mengalami terjadinya penghambatan dalam memberangkatkan calon jamaah haji dengan alasan ada beberapa faktor yang tidak mendukung. Apalagi jika dalam permasalahan pelayanan yang kurang baik maka itu akan menjadi masalah besar dalam sebuah lembaga tersebut dan menjadi tidak minatnya calon jamaah untuk mendaftar kan dirinya kepada KBIH tersebut. Hal ini menjadi faktor utama setiap $\mathrm{KBIH}$ untuk bersaing secara sehat melalui beragam pelayanan yang ditawarkan kepada jamaah. Terbukti dengan pelayanan prima yang diberikan KBIH terhadap jamaah memicu partisipasi calon jamaah yang bergabung dengan KBIH. Begitupula pelayanan prima yang dilakukan KBIH Maqdis terhadap jamaahnya.

Kelompok bimbingan ibadah haji (KBIH) merupakan salah satu organisasi dakwah yang bertugas untuk membantu proses pelayanan ibadah haji di Indonesia. KBIH merupakan lembaga atau yayasan sosial islam dan pemerintah bergerak di bidang bimbingan manasik haji terhadap calon jamaah haji baik selama dalam pembekalan di tanah air maupun pada saat pelaksanaan ibadah haji di Arab Saudi. KBIH sebagai lembaga sosial keagamaan (non pemerintah) telah memiliki legalitas pembimbing melalui Undang-Undang (Aziz, 2007:17).

Pelayanan dan bantuan yang diberikan KBIH baik dalam bentuk manasik teknis maupun manasik ibadah haji, yang disatukan dalam bentuk kegiatan manasik haji (teori dan praktik). Disamping itu, dalam memberikan pelayanan prima, KBIH juga mengikutsertakan pembimbing teknis dan ibadah langsung ke Arab Saudi. Dalam melaksanakan tugasnya sebagai pembimbing haji $\mathrm{KBIH}$ senantiasa berkoordinasi dan berkonsultasi dengan para petugas kloter (TPHI, TPIHI, dan TKHI) baik dalam persiapan keberangkatan (manasik), dalam perjalanan, maupun selama di Arab Saudi. Kemudian KBIH menjadi sangat strategis dan menjadi jembatan antara calon jamaah haji dengan pemerintah.

Terkait dengan kompleksitas permasalahan-permasalahan yang muncul dalam menyelenggarakan ibadah haji setiap tahunnya, menuntut kembali tatanan penyelenggaraan ibadah agar efektif dan efisien. Terlebih mengenai pelayanan yang selalu menjadi tranding topik penyelenggaraan ibadah haji. Mengingat hal tersebut, banyak pihak atau lembaga yang berusaha membantu para calon jamaah haji dalam memberikan pelayanan yang optimal, begitupula dengan lembaga dakwah KBIH Maqdis yang terletak di Kota Bandung.

Untuk mencapai tujuannya setiap KBIH mengarahkan kegiatannya untuk menghasilkan pelayanan yang dapat memberikan kepuasan kepada jamaah, 
sehingga dengan mempertahankan pelayanan menjadi investasi jangka panjang dengan melalui pelayanan yang baik, maka setiap KBIH menciptakan dan membina jamaah. Begitu juga dengan KBIH Maqdis dalam memberikan kepuasan kepada jamaahnya adalah dengan memberikan pelayanan yang terbaik yang sangat berpengaruh terhadap citra lembaga atau perusahaan. Sehingga ranting sebuah lembaga yang memiliki cara ditentukan oleh kepuasan pelanggan atau jamaah terhadap pelayanannya.

Dengan melihat nomena-nomena yang terjadi harus menjadi catatan bagi setiap lembaga dan perusahaan khususnya KBIH dalam memberikan pelayanan terhadap jamaah haji. Tidak hanya mempertahankan saja namun bagaimana sebuah lembaga KBIH mampu mengembangkan dan meningkatkan pelayanan terbaik bagi jamaahnya. Sehingga diperlukan perencanaan yang matang dalam pelayanan yang akan diberikan kepada jamaah.

Dari pemaparan diatas, penulis tertarik untuk melakukan penelitian pada KBIH Maqdis sebagai penyelenggara kelompok bimbingan ibadah haji yang berdiri sejak 2001 yang terakreditasi A. KBIH Maqdis memiliki citra yang baik di masyarakat terbukti sampai sekarang signifikan dalam memberangkatkan jamaahnya. Pertumbuhan jamaah pada angkatan I mendapat respon yang baik dari calon jamaah sehingga KBIH Maqdis memberangkatkan jamaah haji. Pertumbuhan jamaah angkatan 11 dan angkatan $12 \mathrm{KBIH}$ Maqdis memberangkatkan 91 orang jamaah haji secara konsisten.

Manasik haji gratis yang diselenggarakan KBIH Maqdis merupakan salah satu pelayanan prima yang ditawarkan kepada para calon jamaah. Respon masyarakat terhadap KBIH Maqdis ini sangat baik, serta manasik haji yang diselenggarakan selalu banyak diikuti oleh para calon jamaah haji dari berbagai kalangan. Adapun pelayanan lainnya yang menjadi program unggulan dari KBIH Maqdis yaitu tahsin interaktif selama manasik.

Pelayanan pra dan pasca haji sangat diperhatikan oleh KBIH Maqdis. Pembimbing ibadah haji yang diikutsertakan merupakan pembimbing haji yang profesional. Selain pelayanan ibadah haji yang mendapat perhatian, jamaah pun mendapat ziarah tambahan di Makkah dan Madinah. Adapun pasca haji selalu diadakan reunian dan silaturahmi setiap tahunnya. Bahkan tidak hanya itu KBIH Maqdis mempunyai program khusus bagi alumni haji dengan adanya kelompok majelis ta'lim alumni.

\section{LANDASAN TEORITIS}

Teori yang digunakan dalam penelitian ini adalah teori manajemen strategi, teori kuliatas dan teori pelayanan. Manajemen strategi di lingkungan organisasi terdapat beberapa manfaat yang dapat memperkuat usaha mewujudkannya secara efektif dan efisien. Manfaat yang dipetik adalah "manajemen strategi dapat mengurangi ketidakpastian dan kekomplekan dalam menyusun perencanaan sebagai fungsi 
manajemen dan dalam proses pelaksanaan pekerjaan dengan menggunakan semua sumber daya yang secara nyata dimiliki melalui proses yang terintegrasi dengan fungsi manajemen yang lainnya dan dapat dinilai hasilnya sesuai dengan tujuan organisasi”.

Tujuan strategi menurut pandangan Joh. M. Bryson dalam Siti Bilqis (2016:21) adalah untuk menyiapkan organisasi terhadap berbagai ancaman dan peluang eksternal yang mungkin membutuhkan tanggapan dimasa yang akan datang yang dapat digunakan. Dengan demikian tujuan strategi adalah mempersiapkan organisasi tanggapan secara efektif kepada dunia luar sebelum muncul krisis. Segala tindakan harus diambil ketika tindakan ini diidentifikasi dan bermanfaat serta memiliki tujuan.

Strategi merupakan rencana tindakan organisasi untuk mencapai misinya. Setiap wilayah fungsional mempunyai strategi untuk mencapai misinya dan membantu organisasi mencapai misi keseluruhan. Perencanaan secara ringkas berarti suatu rangkaian proses kegiatan menyiapkan dan menentukan seperangkat keputusan mengeni apa yang diharapkan terjadi dan apa yang akan dilakukan (Kusnawan, 2010:902).

Proses yang diuraikan menganggap bahwa penyusunan strategi adalah obyektif secara analisis dalam memperhitungkan kemampuan relatif perusahaan mereka dan kesempatan yang meraka lihat atau harapkan dalam mengembangkan pasar. Tingkat tinggi atau rendah yang mereka ambil tergantung pada sasaran keuntungan mereka. Makin tinggi mereka tentukan, semakin bersedia seharusnya mereka untuk menanggung resiko tinggi pasar yang mereka lihat tidak akan berkembang.

Perumusan strategi seringkali ditunjukan sebagai perencanaan strategi atau jangka panjang. Proses perumusan berurusan dengan pengembangan misi, tujuan, strategi, dan kebijakan perusahaan. Agar semua dapat tercapai, pembuat strategi harus bisa menganalisis faktor strategis perusahaan (kekuatan, kelemahan, peluang, dan acaman) pada situasi sekarang (Hunger, 2003:192).

Pelaksanaan strategi yang efektif dapat menjadikan keputusan strategi yang baik menjadi tidak efektif, atau pilihan yang diragukan menjadi berhasil, adalah sama pentingnya untuk menyelidiki proses-proses pelaksanaan guna mempertimbangkan keuntungan pilihan strategi yang ada. Oleh karena itu, setiap manajer operasional harus mampu mengawasi pelaksanaan perencanaan strategi sampai pada tingkat pengawasan lini pertama dan untuk mendukung hal tersebut, setiap karyawan dalam berbagai cara harus dilibatkan dalam berbagai proses implementasi strategi yang ada, baik tingkat korporasi, unit bisnis maupun fungsional (Andrews, 1985:27).

Kelompok bimbingan ibadah haji adalah lembaga/yayasan sosial islam yang bergerak dibidang bimbingan manasik/ibadah haji terhadap calon jemaah haji, 
baik selama dalam pembekalan di tanah air maupun pada saat pelaksanaan ibadah haji di Arab Saudi.

$\mathrm{KBIH}$ sebagai suatu lembaga sosial keagamaan yang menyelenggarakan bimbingan ibadah haji terhadap calon jemaah haji adalah organisasi dari organisasi induk (pemerintah, khususnya Departemen Agama) yang berbadan hukum dan mempunyai program kerja untuk membimbing dan membina calon jemaah haji.

Tujuan diselenggarakan bimbingan ibadah haji oleh $\mathrm{KBIH}$ adalah utnuk memberikan pelayanan bimbingan dan iformasi hal-hal yang berkaitan dengan pelaksanaan manasik haji. Keberadaan KBIH sebagai salah satu swadaya masyarakat diharapkan mampu membantu pemerintah dalam hal pembimbingan calon jamaah haji dengan tetap mendapatkan totalitas pelayanan yang medepankan keamanan, kenyamanan, dan ketertiban selama melaksanakan ibadah haji.

Peningkatan secara epistemologi adalah menaikkan derajat taraf dan sebagainya mempertinggi memperhebat produksi dan lain sebagainya serta proses cara perbuatan meningkatkan usaha. Peningkatan juga bisa dilihat dari kualitas atau mutu, maksudnya tingkat dimana rancangan spesifikasi sebuah produk atau jasa sesuai dengan fungsi dan penggunaannya. Disamping itu kualitas adalah tingkat dimana sebuah produk dan jasa sesuai dengan rancangan spesifikasinya. Jadi mutu (quality) juga dapat dikatakan sebuah filosofis dan metodologis tentang (ukuran) dan tingkat baik suatu produk atau jasa yang membantu institusi untuk merencanakan perubahan dan mengatur agenda rancangan spesifikasi sebuah produk barang atau jasa sesuai dengan fungsi dan penggunaannya agenda dalam menghadapi tekanan-tekanan eksternal yang berlebihan (Sumayang, 2003: 322).

Menurut mengatakan bahwa, faktor-faktor yang perlu dipertimbangkan dalam meningkatkan kualitas pelayanan tidaklah semudah membalikkan telapak tangan, banyak faktor yang harus diperhatikan secara cermat, karena semua upaya penyempurnaan kualitas pelayanan akan berdampak signifikan terhadap budaya organisasi secara keseluruhan (Fandy, 2011: 182-189).

Pelayanan diartikan sebagai tindakan atau perbuatan yang diberikan seseorang atau organisasi untuk memberikan kepuasan kepada pelanggan atau konsumen. Secara etimologis, Kamus Besar bahasa Indonesia (Daryanto, 2014: 107), menyatakan bahwa pelayanan adalah Pelayanan pada dasarnya merupakan kegiatan yang ditawarkan kepada konsumen atau pelanggan, yang bersifat tidak berwujud dan tidak dapat dimiliki.

Tujuan pelayanan prima adalah memberikan pelayanan yang bisa memenuhi dan memuaskan hati pelanggan atau masyarakat serta memberikan fokus pelayanan kepada pelanggan. Pelayanan prima dalam sektor publik yang didasarkan pada aksioma bahwa "pelayanan adalah pemberdayaan". Pelayanan pada sektor bisnis berorientasi profit, sedangkan pelayanan prima pada sektor publik bertujuan memenuhi kebutuhan masyarakat secara sangat baik atau terbaik. Apabila pelayanannya kurang baik dan kurang memuaskan maka tentu saja akan 
timbul mengecewakan terhadap pelanggan. (Fandy, 2011: 182-189)

Tujuan dari pelayanan prima adalah untuk memberikan pelayanan yang bisa memenuhi dan memuaskan para pelanggan atau masyarakat serta memberikan fokus pelayanan kepada pelanggan. Adapun pelayanan pada sektor swasta tentunya pelayanan selalu bertujuan atau berorientasi untuk keuntungan perusahaan, pelayanan prima akan bermanfaat bagi upaya peningkatan kualitas pelayanan serta acuan untuk mengembangkan standar pelayanan.

Haji dalam bahasa arab "berarti menuju suatu tempat berualang kali menuju ke suatu yang dibesarkan" istilah tersebut terkait dengan kunjungan kaum muslimin ke baitullah ditiap-tiap tahun (berulang-ulang), sehingga ibadah tersebut disebut haji atau mengingat baitullah merupakan tempat yang di besarkan, sehingga kegiatan ibadah yang mengunjungi tempat tersebut dinamakan haji.

Dalam perspektif fiqh para ulama berpendapat bahwa kata "haji" memiliki pengertin khusus. Yankni mengunjungi ka'bah untuk melaksanakan manasik haji. Makna "hajjul bait" menurut saya adalah mengunjungi baitullah dengan sifat tertentu, diwaktu tertentu disertai perbuatan-perbuatan tertentu pula.

Haji menurut bahasa adalah tujuan, maksud dan menyengaja. Bahwa lafal "haji" memakai fatha awalnya dan boleh juga dengan kasrah, menurut lughot ialah menyengaja atau banyak menyengaja kepada sesuatu yang diagungkan para sufi juga mengemukakan tentang haji bahwa wajib haji bagi setiap muslim yang berakal sehat yang mampu melaksanakannya dan telah mencapai kedewasaannya. Haji itu adalah memakai pakaian haji (ihram) pada tempat yang ditentukan, tingal di A'rafah, mengelilingi ka'bah, dan berlari antara Shafa dan Marwah (Dahlan, 1997: 458).

\section{HASIL DAN PEMBAHASAN}

Lokasi yang dijadikan sebagai tempat penelitian ini dilakukan di KBIH Maqdis MIM Blok D-20 yang berada di Jl. Soekarno Hatta N0. 590 Kota Bandung. Alasannya adalah karena topik yang dibahas dalam penelitian ini sangat penting untuk diketahui oleh siapapun yang berkaitan dengan Strategi Kelompok Bimbingan Ibadah Haji (KBIH) dalam Meningkatkan Pelayanan Prima Terhadap Calon Jemaah Haji Tahun 2017. Hal ini sangat penting terutama untuk aktivitas $\mathrm{KBIH}$ tersebut.

Temuan dari penelitian ini adalah konsep strategi pelayanan prima $\mathrm{KBIH}$ maqdis, implementasi strategis pelayanan prima KBIH Maqdis dan evaluasi strategis pelayanan prima KBIH Maqdis.

\section{Konsep Strategi Pelayanan Prima KBIH Maqdis}

Keberhasilan dalam mengembangkan dan melaksanakan pelayanan prima tidak terlepas dari kemampuan dalam pemilihan konsep strategi. Konsep strategi 
pelayanan prima tidak terlepas dari A6 menurut Barata (2003: 15) yaitu menyelaraskan konsep-konsep diantaranya: Pertama, kemampuan (ability). Karyawan KBIH Maqdis memiliki kemampuan serta mempunyai ahli dalam bidangnya masing-masing. Salah satunya yaitu KBIH Maqdis memiliki pembimbing haji yang profesional dalam artian pembimbing haji yamg berilmu, berpengalaman, dan bertanggung jawab. Dengan demikian konsep strategi pelayanan prima akan tercipta dalam pemberian pelayanan oleh karyawan $\mathrm{KBIH}$ Maqdis kepada jamaah haji Berdasarkan hasil wawancara Pak Nunu Nur arifin mengatakan bahwa:

"Semua karyawan KBIH Maqdis telah teruji kemampuan sesuai bidangnya. Terlebih KBIH Maqdis sangat memperhatikan para pembimbing calon jamaah haji serta ada beberapa indikator yang penting dalam prekrutan calon pembimbing haji. Bagi KBIH Maqdis memberikan pelayanan yang baik merupakan hal yang penting bagi jamaah dengan harapan kemabruran jamaah haji setelah perpulangan dari tanah suci sehingga tak terlepas dari peran serta para pembimbing haji yang baik dalam keilmuan dan pengalamannya. Harus mempunyai rasa memiliki terhadap KBIH maqdis dan rasa memiliki terhadap pekerjaan juga. Kemudian harus mempunyai loyalitas yang tinggi terhadap pekerjaan serta menjaga nama baik KBIH maqdis" (Wawancara pada hari Sabtu, 19 Mei 2018).

KBIH Maqdis ini suatu lembaga yang satu kesatuan, serta terpadu untuk bisa mencapai sasaran serta menjadi salah satu poin terpenting agar menjadi kekuatan, tenaga, cara dan guna yang artinya bisa bermanfaat dan berfaedah. Maka dengan keseluruhan seluruh staf yang berada di dalam KBIH maqdis telah menjalankan tugasnya dengan baik dan amanah. Dan para calon jamaah atau jamaah haji pun merasa puas dengan apa yang diberikan oleh $\mathrm{KBIH}$ maqdis kepada jamaah haji.

Kedua, Sikap (attitude). Dengan menciptakan sikap yang baik maka akan terjalin pula hubungan yang baik dengan calon jamaah haji yang akan bergabung dengan KBIH Maqdis. Sehingga seluruh karyawan KBIH Maqdis memiliki akhlakul karimah.

Akhlakul karimah merupakan sikap yang tercermin dari karyawan $\mathrm{KBIH}$ Maqdis. rasa memiliki terhadap KBIH Maqdis sangat tinggi, kebanggaan dan loyalitas karyawan terhadap pekerjaannya yang tercermin dari kehadiran para karyawan yang tepat waktu, serta selalu menjaga nama baik KBIH Maqdis dengan memberikan pelayanan yang baik serta sopan santun dalam pelayanan.

Berdasarkan wawancara bersama Pak Nunu Nur arifin, bahwa:

"Sikap merupakan indikator yang paling penting yang harus dimiliki oleh 
setiap karyawan KBIH Maqdis, meskipun seseorang mempuni dalam suatu bidang namun memiliki sikap yang kurang baik maka KBIH Maqdis tak menghiraukan itu semua. Oleh karena itu KBIH sangat selektif dalam memperhatikan sikap para karyawan" (Wawancara pada hari Sabtu, 19 Mei 2018)

Dari uraian dapat disimpulkan bahwa sikap yang diberikan pada saat melayani calon jamaah atau pelanggan menggunakan 5S, Senyum, Salam, Sapa, Sopan, dan Santun agar para calon jamaah atau jamaah itu merasa puas dengan pelayanannya. Demikian pula sikap yang semestinya atau yang wajar diberikan kepada setiap pelanggan akan membuat pelanggan senang. Sikap kita dalam melayani pelanggan atau calon jamaah haji terkadang timbul dari dalam naluri kita sendiri, kebiasaan kita berhubungan dengan pelanggan akan memudahkan kita untuk berinteraksi langsung.

Ketiga, penampilan (appreance). Selain dalam selain dalam memperhatikan sikap yang berakhlakul karimah, KBIH Maqdis juga memperhatikan karyawan yang memiliki penampilan yang rapi dalam memberikan pelayanan kepada jamaah. Untuk karyawan perempuan memakai pakaian muslim syar'i, sedangkan yang lakilaki memakai pakaian rapi. dan KBIH Maqdis mempunyai seragam yang dipakai pada sehari-hari.

Keempat, Perhatian (attention). Karyawan KBIH Maqdis membantu calon jemaah haji dalam melengkapi dokumen pemberangkatan ibadah haji, membantu pemeriksaan kesehatan tahap satu dan tahap dua. Dan memenuhi kebutuhan jamaah dengan memberikan perhatian dalam pelayanannya. Hasil wawancara dengan pak Nunu Nur arifin mengatakan bahwa:

“KBIH Maqdis itu membimbing jamaah haji dalam mengkaji Al-Qur'an, karena selain bimbingan dengan teori dan praktik jamaah haji juga ada jadwal bimbingan mentadaburi Al-Qur'an yang dimulai dengan program dasar melancarkan bacaan Al-Qur'an, memperbaiki bacaan Al-Qur'an serta pendalaman terhadap ilmu Al-Qur'an. Hal ini menjadi pembeda anatara KBIH Maqdis dengan KBIH lainnya, tutur beliau" (Wawancara pada hari Sabtu, 19 Mei 2018)

Menurut saya ini sangat bagus dengan adanya pembelajaran serta bimbingan tentang Al-Qur'an juga. Jadi para calon jamaah itu tidak hanya diberikan pemahaman materi tantang tata cara haji tetapi KBIH maqdis juga membimbing serta mengajak calon jamaah haji untuk selalu membaca Al-Qur'an. Dengan adanya pembelajaran serta bimbingan ini calon jamaah bisa memperbaiki dan mendalami ilmu tentang Al-Qur'an yang belum dipahami. 
Kelima, Tindakan (action). Selalu berusaha meningkatkan perbaikan mutu dengan cepat dan tepat dalam melayani saran dan kritik para jamaah. Maka itu KBIH Maqdis dengan cepat tanggap dalam memenuhi kebutuhan pelanggan, baik itu pelanggan internal maupun eksternal yaitu peluang dan ancaman/tantangan maupun kekuatan dan kelemahan lembaga untuk mengantisipasi perubahan yang terjadi. Maka KBIH Maqdis mampu berusaha untuk menjadi lembaga yang baik dan amanah dalam menjalankan fungsinya. Hasil wawancara dengan Farhan Mubarok bahwa: "KBIH Maqdis selalu berusaha memberikan pelayanan yang terbaik kepada jamaahnya apapun itu selama berkaitan dengan pelayanan jamaah haji" (Wawancara hari Sabtu, 19 Mei 2018)

Selain berkaitan tentang haji saja menurut penulis KBIH Maqdis ini selalu memberikan tindakan yang siap siaga dengan pelanggan yang berdatangan ke $\mathrm{KBIH}$ Maqdis. Bahkan ketika penulis mendatangi salah satu staf KBIH mereka langsung siap siaga untuk memberi pelayanan agar para pelangan tidak kecewa dengan pelayanan yang sangat ramah.

Keenam, tanggung jawab. Memiliki tanggung jawab yang tinggi serta mengantisipasi dalam pemberian pelayanan kepada calon jamaah. Melayani adalah tanggung jawab dalam kemmapuan untuk memberikan semua kulitas terbaik untuk melayani kebutuhan pelanggan. Semakin banyak kualitas melayani kebutuhan pelanggan akan menjadi sangat efektif dalam memenuhi kebutuhan KBIH. Hasil wawancara dengan Farhan Mubarok bahwa:

"Pelayanan dari hati akan memberikan rasa kepuasan tersendiri, karena bila sudah sudah memiliki rasa cinta dan pengabdian untuk memberikan yang terbaik dalam pekerjaan. Jadi tidak hanya sekedar cukup dari ambisi saja tapi rasa tanggung jawab juga harus jadi salah satu kewajiban terpenting dalam melayani” (Wawancara pada hari Sabtu, 19 Mei 2018)

Tanggung jawab dari pelayanan KBIH Maqdis sangat sangat baik, karena para staf KBIH Maqdis sudah terbiasa dengan melayani calon jamaah haji dengan tulus dan ikhlas. Yang dilakukan KBIH Maqdis mempunyai kelebihan dalam melayani dengan penuh perhatian, totalitas, tulus dan ikhlas menurut penulis itu sangat menciptakan kesuksesan dalam memberikan pelayanan yang terbaik.

Strategi merupakan rencana tindakan organisasi untuk mencapai misinya. Setiap wilayah fungsional mempunyai strategi untuk mencapai misinya dan membantu organisasi mencapai misi keseluruhan. Perencanaan secara ringkas berarti suatu rangkaian proses kegiatan menyiapkan dan menentukan seperangkat keputusan mengeni apa yang diharapkan terjadi dan apa yang akan dilakukan (Kusnawan, 2010:902).

Perumusan strategi seringkali ditunjukan sebagai perencanaan strategi atau jangka panjang. Proses perumusan berurusan dengan pengembangan misi, tujuan, 
strategi, dan kebijakan perusahaan. Agar semua dapat tercapai, pembuat strategi harus bisa menganalisis faktor strategis perusahaan (kekuatan, kelemahan, peluang, dan acaman) pada situasi sekarang (Hunger, 2003:192).

\section{Implementasi Strategi Pelayanan KBIH Maqdis}

Untuk mengantarkan setiap jamaah haji mencapai derajat yang mabrur, KBIH Maqdis ini menyediakan materi bimbingan manasik haji dan umroh yang meliputi pembinaan ruhiyah (mental spiritual), fikriyah (ilmu pengetahuan), dan jasadiyah (fisik). Selain itu jamaah juga dibimbing untuk lebih banyak berinteraksi dengan Al-qur'an.

Bimbingan tersebut mesti dilakukan sejak dini sebagai persiapan sebelum pergi, yang akan dilanjutkan di tanah suci sebagai puncak bimbingan ibadah haji dan akan terus berkesinambungan setelah tiba di tanah air. Berikut ini penjelasan bimbingan manasik KBIH Maqdis: Pertama, Bimbingan Manasik haji, diantaranya: (a) Teori manasik haji dan umroh yang dilengkapi dengan bimbingan Aqidah, Syari'ah, dan Akhlak. Maksudnya yaitu supaya dengan adanya manasik haji dengan dilengkapi bimbingan Aqidah, Syariah, dan Akhlak agar para calon jamaah lebih bisa memahami teori manasik; (b) Memberikan pencerahan serta bentuk konstribusi yang jelas agar manasik berjalan sesuai dengan Al-Qur'an dan Sunnah dengan selalu meperhatikan konsep islam sebagai agama yang washatiiyyah dan i'tidal yang berkaitan dengan kewajiban dan rukun-rukun ibadah haji; (c) Praktik manasik haji untuk mempersiapkan melaksanakan ibadah di tanah suci sesuai dengan tuntunan Rasulullah SAW.

Kedua, Bimbingan (Plus) Al-Qur'an, diantaranya: (a) Tahsin Al-Qur'an (perbaikan bacaan Al-Qur'an). Jadi selama manasik KBIH Maqdis ini melakukan kegiatan tahsin Al-Qur'an agar para jamaah tidak hanya teori tentang manasik saja yang mereka pahami tapi jamaah juga bisa melakukan perbaikan bacaan AlQur'annya pada saat manasik dilaksanakan. Jadi ini bisa dibilang sebagai daya tarik $\mathrm{KBIH}$ untuk menarik perhatian calon jamaah untuk bisa bergabung dengan Lembaga KBIH Maqdis ini. (b) Tafsir/ Tadabbur Ayat Al-Qur'an; (c) Tausiyah di Penginapan; (d) Muhasabah di Mina.

"Pembinaan bimbingan manasik haji KBIH Maqdis dilengkapi dengan bimbingan Aqidah, Syariah, dan Akhlak agar para calon jamaah lebih bisa memahami teori manasik. Serta jamaah haji melaksanakan kegiatan membaca Al-Qur'an agar lebih mendalami dan perbaikan bacaan Al-Qur'an pada saat manasik" (Wawancara dengan Ibu Hj. Erna Supartina pada hari Senin, 21 Mei 2018).

Jadi KBIH Maqdis menurut penulis sangat memperhatikan calon jamaahnya. semata-mata melaksanakan ibadah haji ini bukan perihal tamasya atau bermain-main tetapi mendekatkan diri kepada Allah serta dijauhkan dari 
jerumusan maksiat. Wajib bagi jamaah haji untuk melaksanakan yang Allah wajibkan. Sudah selayaknya KBIH Maqdis memberikan arahan, nasehat, dan bantuan kepada calon jamaah haji agar bisa melaksanakan ibadah haji yang mabrur.

Antusias Jamaah Haji dalam Mengikuti Kegiatan

"Jamaah haji KBIH Maqdis sangat antusias saat ada kegiatan yang dilaksanakan KBIH karena pihak KBIH berpesan kepada semua jamaah agar senantiasa mengikuti kegiatan yang dilaksanakan dengan baik sehingga jamaah bisa memahami rukun haji dengan baik dan akhirnya menjalankan ibadah dengan baik serta mabrur. Antusias terbilang bagus dan para calon jamaah serius mendengarkan materi-materi yang disampaikan" (Wawancara bersama Ibu Hj. Erna Supartina pada hari Senin, 21 Mei 2018).

Antusias calon jamaah haji Maqdis terbilang bagus karena bimbingan manasik haji baik teori maupun praktik sangat perlu diikuti oleh calon jamaah haji karena penyelenggaranaan ibadah haji itu merupakan tanggung jawab pemerintah maka perlu adanya bimbingan manasik haji. Manasik ini sebagai bekal untuk calon jamaah sebelum berangkat ke Makkah serta meluruskan niat atau satukan ibadah yang didasari iman islam.

Materi adalah hal yang sangat penting untuk disampaikan kepada calon jamaah haji dalam bimbingan manasik haji karena dengan penyampaian materi calon jamaah haji lebih memudahkan dalam pelaksanaan ibadah haji. Diantara materi yang disampaian pengenalan budaya adat istiadat Bangsa Arab dengan pengenalan budaya Arab diharapkan calon jamaah dapat lebih mandiri di tanah suci kelak. Materi lainnya adalah akhlakul kharimah dan pemahaman ibadah haji bertujuan agar calon jamaah haji dapat lebih khusu' dalam menunaikan ibadahnya. Ibu Hj. Erna Supartina mengatakan bahwa:

"Untuk materi/kurikulum bimbingan manasik haji di KBIH Maqdis sudah ditetapkan langsung dari Kantor Kementrian Agama sehingga untuk materi semua sama. Tapi dari pihak KBIH sendiri membuat jadwal dan materi sendiri yang sudah lebih dipadatkan materinya tetapi tetap berpedoman dari materi/ kurikulum manasik haji yang telah diberikan dari Kementrian Agama" (Wawancara pada hari Senin, 21 Mei 2018).

Tabel 3.1

Materi Manasik Haji Maqdis

\begin{tabular}{ll}
\hline Materi & Pertemuan \\
\hline Pengantar & \\
Sekilas tentang Maqdis &
\end{tabular}


Pelaksanaan haji Indonesia

Pelaksanaan haji Indonesia

Persiapan yang harus dilakukan

Perbedaan jamaah haji Maqdis

Pengenalan Tempat Ibadah Haji

Pengenalan kota Makkah

Pengenalan Masjidil Haram

Pengenslsn Ka'bah dan Safa Marwah

Pengenalan Mina, Arafah, Muzdalifah

Pengenalan Maktab

Pengenalan makanan di Makkah

Ibadah Haji \& Umroh Menurut Sunnah

Kewajiban haji

Tatacara berpergian

Ihrom

Al Ihrom

Sebelum berihrom

Larangan-larangan berihrom

Macam-macam ibadah haji

Haji Tamattu, Qiran, Ifrad sebelum memasuki hari Tarwiyah

Umroh dan pembahasanya

Thowaf umroh

Catatan penting saat thowaf

Sa’i umroh

Bukit Marwah

Haji dan pembahasannya

Rukun haji dan Wajib haji

Tanggal 8 Dzulhijjah

Tanggal 9 Dzulhijjah

Muzdalifah jamaah tiba di Mina tanggal 10 Dzulhijjah

Melempar Jamarat

Tadbir: Jurnal Manajemen Dakwah Vol. 2 No. 3 (2017) 287-308 
N.Oktaviani, A.Rahman dan Herman

Thowaf Ifadah

Hari-hari Tasyrik

Thowaf Wada'

Hukum-hukum khusus untuk mu'minat

Tatacara ziarah Masjid Nabawi

Doa-doa pilihan

Tempat Bersejarah \& Tempat Tinggal Madinah

Tempat-tempat bersejaran di Makkah

Kota Madinah

Masjid Nabawi

Tempat-tempat bersejarah di Madinah

Tempat tinggal di Mandinah

Perjalanan Haji Maqdis

Praktik Lapangan

Review Seluruh Materi Manasik

Berbagi Pengalaman Alumni

Total Pertemuan 13

Sumber: Erna Supartina (Wawancara pada hari Senin, 21 Mei 2018).

Program Kerja KBIH Maqdis, berdasarkan hasil wawancara dengan Pak Nunu Nur Arifin, S.Pd.I mengatakan bahwa:

"Program kerja KBIH maqdis tidak pernah berubah siklusnya seperti pemaparan tabel di lampiran sedangkan waktunya disesuaikan. Program kerja ini menjadi acuan dasar pelayanan semua kegiatan KBIH Maqdis setiap tahunnya. Kelompok bimbingan ibadah haji $(\mathrm{KBIH})$ maqdis memiliki program yang hampir sama dengan semua lembaga bimbingan haji. Program tersebut merupakan ketentuan dari Departemen Agama secara formal yaitu tentang bimbingan haji yang mendekat dengan program yayasan Maqdis" (Wawancara pada hari Sabtu, 19 Mei 2018).

Oleh karena itu, program ini disusun berdasarkan keberangkatan dan kepulangan dari pemerintah KEMENAG dan program ini bersifat "tentatif" artinya sangat memungkinkan bahwa untuk adanya perubahan (waktu dan agenda kegiatan).

Kegiatan bulan Januari dilakukan pra manasik haji (teori) dan gratis bagi umum, yang merupakan sebagai strategi pemasaran dan pengenalan KBIH Maqdis kepada masyarakat, khususnya bagi calon jamaah haji. Setelah melakukan promosi 
melalui media sosial, pamplet, dan pra manasik kepada masyarakat umum, maka pada bulan Januari KBIH maqdis sudah dibuka pendaftaran bagi calon jamaah haji. Perencanaan akan kegiatan-kegiatan bimbingan ibadah haji sudah disusun matang seperti penentuan lokasi penyampaian materi bimbingan baik teori maupun praktek, serta penentuan pembimbing haji. Selain itu pada bulan Januari menjadi acara rutin reuni bagi angkatan sebelumnya yang telah melaksanakan ibadah haji.

Kegiatan pada bulan Februari KBIH Maqdis masih membuka pendaftaran bagi calon jamaah haji serta KBIH melakukan promosi kepada calon jamaah dan publikasi di media sosial dan pamplet. Selanjutnya pemeriksaan kelengkapan data para jamaah serta fiksasi tempat bimbingan ibadah haji dan pembimbing ibadah haji. Kemudian pada bulan Maret kegiatan bimbingan ibadah haji mulai dilakukan. Kegiatan promosi dan publikasi serta pendaftaran pun masih terbuka bagi calon jamaah haji.

Pada bulan April bimbingan manasik haji lanjutan dari bulan Maret serta pelaksanaan bimbingan ibadah haji praktek. Proses paspor jamaah yang sudah terdaftar pun sudah dimulai pada bulan ini. Selanjutnya bulan Mei dilakukan bimbingan ibadah haji lanjutan dan pendaftaran bagi jamaah haji.

Selanjutnya pada bulan Juni dilaksanakan bimbingan ibadah haji yang merupakan lanjutan pada bulan Mei. Proses mutasi jamaah haji mulai dilakukan oleh pemerintah (Kemenag). Pemeriksaan kesehatan dan check up calon jamaah haji dilakukan di puskesmas. Penyelesaian paspor calon jamaah haji oleh pemerintah (Kemenag) serta pelunasan BPIH tahap satu.

Agenda pada bulan Juli merupakan penyelesaian mutasi calon jamaah haji yang dilakukan oleh pemerintah (Kemenag). Kemudian pelunasan BPIH tahap 2 dan tahap 3 serta registrasi dan legalisir BPIH.

Selanjutnya bulan Agustus agenda kegiatan rutin gabungan bimbingan ibadah haji se-kota Bandung yang dilaksanakan di Pusda'i. Tes kebugaran jasmani calon jamaah haji dilaksanakan di Lottemart. Pembinaan para ketua regu dan ketua rombongan, distribusi dan pembagian batik bagi calon jamaah haji. Kemudian manasik gabungan se-kota Bandung dilaksanakan di Lapangan Zifur Ujung Berung. Vaksinasi meningitis dan influensi dilakukan di puskesmas. Selanjutnya pembahasan mengenai teknis pemberangkatan jamaah haji.

Pada bulan September koordinasi Karu, Karom, Kloter, TPHI, TPIHI, dan Pembimbing oleh Kemenag serta KBIH Maqdis. Distribusi koper, ransel, syal dan tanda pengenal jamaah Indonesia lainnya dari Kemenag ke KBIH Maqdis. Setelah itu dibagikan kepada calon jamaah haji, kemudian koper dikumpulkan kembali pada waktu yang telah ditentukan. Pemberangkatan jamaah haji di embarkasi Bekasi.

Pada bulan Oktober KBIH Maqdis membuat pengajuan tempat kepulangan 
jamaah haji. Pembuatan laporan haji 2017 KBIH Maqdis. Perpulangan jamaah haji berkumpul di KBIH Maaqdis. Selanjutnya laporan ibadah haji kBIH Maqdis diserahkan ke Kemenag.

Selanjutnya pada bulan November dilakukan bimbingan pasca haji Maqdis dengan melakukan reuni angkatan jamaah haji. Selain sebagai ajang silaturahmi juga sebagai evaluasi internal ketika pelaksanaan haji di tanah suci.

Terakhir pada bulan Desember mulai dilaksanakan promosi dan publikasi KBIH Maqdis kepada masyarakat luas dengan diadakannya manasik haji gratis baik teori maupun praktek. KBIH Maqdis mengadakan seminar haji dan umroh secara gratis bagi masyarakat umum. Silaturahmi lanjutan dengan para alumni jamaah haji KBIH Maqdis.

KBIH Maqdis memiliki program pada dua kategori, yakni program yang berkenaan dengan bimbingan haji dan program kelembagaan yang berdasarkan ketentuan Departemen Agama di antaranya:

Program yang terkait dengan ibadah haji merupakan tugas pokok dari KBIH Maqdis, proses awal yang dilakukan adalah melakukan berbagai upaya untuk menarik calon jamaah haji dalam mengikuti program-program yang ditawarkan oleh KBIH Maqdis dengan cara melakukan sosialisasi kepada masyarakat untuk menawarkan program tersebut. Berdasarkan hasil wawancara Ibu Hj. Erna Supartina bahwa:

"Bimbingan itu proses yang dilakukan untuk mempersiapkan calon jamaah haji sebelum menjalankan ibadah haji di tanah suci. Calon jamaah haji yang mempercayakan dirinya dibimbing pada KBIH Maqdis telah mendaftarkan diri akan dilakukan pembinaan intensif agar para calon jamaah haji bisa menyesuaikan diri ketika berada di Makkah" (Wawancara pada hari Sabtu, 19 Mei 2018).

Bimbingan di tanah suci, yakni membimbing pemahaman keagamaan secara umum. Hal ini dimaksudkan agar para jamaah haji dapat memahami atau mengerti setiap proses dalam pelaksanaan ibadah haji sehinggan dapat menjadi haji yang mabrur. Setelah melaksanakan bimbingan manasik selesai, para jamaah akan diberangkatkan sesuai jadwal keberangkatan yang telah ditetapkan.

Memberangkatkan jamaah haji merupakan gerbang untuk melangkah pada pelaksanaan ibadah haji yang sebenarnya di tanah suci.

Setelah jamaah haji pulang ke tanah air KBIH Maqdis melaksanakan program pembinaan lanjutan, yaitu pembinaan berkala agar apa yang telah didapat dari perjalanan haji tersebut terus membawa manfaat. Jamaah yang sudah menyelesaikan ibadah haji secara langsung sudah masuk ke dalam sebuah ikatan alumni jamaah haji KBIH Maqdis. Adapun pembinaan secara langsung yakni mengundang seluruh alumni jamaah haji untuk menghadiri acara tausiah dan 
pengajian. Selain itu KBIH pun memberikan berbagai informasi tentang programprogram yang ada didalamnya. Secara tidak langsung hal ini terlaksana di dalam acara-acara yang diselenggarakan oleh alumni jamaah haji dari KBIH Maqdis itu sendiri yang kedua belah pihak terlibat didalamnya. Berdasarkan hasil wawancara bersama Pak Nunu Nur Arifin, S.Pd.I mengatakan bahwa:

"KBIH Maqdis memiliki beberapa program kerja selain yang terkait langsung dengan masalah ibadah haji, yaitu program yang berkaitan dengan yayasan Maqdis. KBIH Maqdis pun memberikan pembinaan pembelajaran Al-Qur'anserta memberikan pemahaman keagamaan yang berkaitan dengan ibadah haji” (Wawancara pada hari Sabtu, 19 Mei 2018).

Perlu adanya penyusunan langkah-langkah yang tepat untuk bisa mencapai tujuan lembaga. Diperlukan analisis terhadap lingkungan, baik lingkungan eksternal maupun lingkungan internal, yaitu peluang dan ancaman/tantangan maupun kekuatan dan kelemahan lembaga untuk mengantisipasi perubahan yang terjadi.

Strategi pendayagunaan menjadi salah satu poin penting yang menjadi kekuatan, tenaga, cara dan guna yang artinya faedah dan manfaat. Adapun definisi pendayagunaan yakni proses, cara untuk memanfaatkan. Jadi proses atau pelaksanaan ketika membimbing jamaah baik berupa memberikan materi praktik tentang haji dan membimbing jamaah dalam mengkaji Al-Qur'an KBIH Maqdis memang harus benar-benar memanfaatkan situasi supaya memberikan kepuasan kepada jamaah haji. Pak Nunu Nurarifin mengatakan bahwa:

"KBIH Maqdis adalah lembaga kelompok bimbingan ibadah haji yang menghimpun masyarakat untuk memberangkatkan masyarakat yang hendak untuk berhaji serta membimbing calon jamaah" (Wawancara pada hari Senin, 28 Mei 2018)

Tugas yang dilakukan oleh KBIH Maqdis ini secara merata dijalankan pula sesuai dengan ketentuan yang berlaku dari Kementrian Agama. Maka KBIH Maqdis sudah mampu menjadi lembaga manasik haji yang baik dan amanah dalam menjalankan tugasnya. KBIH Maqdis secara berkesinambungan, artinya mampu menghasilkan manfaat dan faedah yang berkepanjangan, tidak hanya bermanfaat secara sesaat saja, namun mampu bergulir secara jangka panjang dengan merutinkan jadwal silaturahmi sesama jamaah.

"Sasaran yang terdiri dari visi, misi, dan tujuan ini menjadi salah satu elemen strategi pelayanan yang dikehendaki beserta kebijakan dan rencana-rencana. Ketiga elemen ini akan menghasilkan strategi pelayanan yang dikehendaki yang menjadi acuan penilaian teori dengan bagaimana hasil yang terdapat di 
lapangan" (Wawancara dengan Ibu Hj. Erna Supartina pada hari Senin 28 Mei 2018).

Meningkatkan pelayanaan dan fasilitas untuk kebutuhan jamaah haji memberikan bimbingan membantu proses pendaftaran. Meningkatkan pelayanan dan fasilitas untuk kebutuhan jamaah, membantu memberikan pengarahan dan bimbingan kepada calon jamah haji. Lebih. pelaksanaan yang terdapat pada visi, misi, dan tujuan supaya tingkat pelayanan yang diberikan kepada jamaah lebih maksimal. Untuk perbaikan manajemen KBIH dan peningkatan kepercayaan jamaah mengingat semakin banyaknya pesaing.

Pelaksanaan strategi yang efektif dapat menjadikan keputusan strategi yang baik menjadi tidak efektif, atau pilihan yang diragukan menjadi berhasil, adalah sama pentingnya untuk menyelidiki proses-proses pelaksanaan guna mempertimbangkan keuntungan pilihan strategi yang ada. Oleh karena itu, setiap manajer operasional harus mampu mengawasi pelaksanaan perencanaan strategi sampai pada tingkat pengawasan lini pertama dan untuk mendukung hal tersebut, setiap karyawan dalam berbagai cara harus dilibatkan dalam berbagai proses implementasi strategi yang ada, baik tingkat korporasi, unit bisnis maupun fungsional (Andrews, 1985:27).

Tujuan dari pelayanan prima yaitu memberikan pelayanan yang bisa memenuhi dan memuaskan hati pelanggan atau masyarakat serta memberikan fokus pelayanan kepada pelanggan. Pelayanan prima dalam sektor publik yang didasarkan pada aksioma bahwa "pelayanan adalah pemberdayaan". Pelayanan pada sektor bisnis berorientasi profit, sedangkan pelayanan prima pada sektor publik bertujuan memenuhi kebutuhan masyarakat secara sangat baik atau terbaik. Apabila pelayanannya kurang baik dan kurang memuaskan maka tentu saja akan timbul mengecewakan terhadap pelanggan. (Fandy, 2011: 182-189)

\section{Evaluasi Strategi Pelayanan KBIH Maqdis}

Evaluasi strategi adalah suatu proses dengan manajer membandingkan apakah suatu rencana dapat dilaksanakan dengan tepat untuk mencapai tujuan. Mungkin saja dalam pelaksanaan startegi yang dilakukan akan menghasilkan tujuan tercapai, kurang dari atau tidak sama sekali tidak mencapai 100\% semua itu merupakan umpan balik sebagai suatu masukan untuk perbaikan atau membuat strategi yang baru yang lebih tepat untuk mengantisipasi kondisi yang serupa atau mungkin ada pemisahan menurut Steamer yang dikutip Djaslin Saladin (1990:13). Aspek-aspek penting yang dapat dievaluasi umumnya akan menyangkut masalah mutu, pengembangan manajemen, analisa dan diagnose lingkungan.

Evaluasi yang dilakukan di KBIH Maqdis dan pengendalinnya sangat efektif. Dalam praktiknya, pelayanan ini berupaya untuk dasar pengendalian strategi pada pengamatan strategi (strategic surveillance) dan pengendalian strategi 
(premise control) terus menerus oleh pimpinan dan seluruh staf karyawan. Namun, dari sistem kendali yang ada pada KBIH Maqdis ini cukup reksioner yakni perubahan yang terkait dengan pengendalian berupa peringatan khusus selalu didasarkan pada sentralisasi pimpinan. Sebagaimana sudah ditegaskan oleh Farhan Mubarok bahwa:

"evaluasi dari pelayanan yang dilakukan oleh KBIH Maqdis cukup memuaskan. Sehingga pelanggan yang mau mendaftarkan dirinya untuk berhaji dari setiap tahunnya semakin meningkat. Dan semua ini sangat jelas bahwa pelayanan prima yang dilakukan oleh KBIH maqdis ini sudah tertuju kepada excellent service pelayanan yang baik" (Wawancara pada hari Senin, 28 Mei 2018)

KBIH Maqdis ini memperoleh kepuasan tersendiri dari hasil pelayanan yang membuat para pelanggan atau calon jamaah haji itu merasakan kenyamanan, tanggung jawab, profesionalitas, dan pertumbuhan kepercayaan terhadap pelanggan. Yang dilakukan staf KBIH Maqdis sudah memenuhi harapan para pelanggan sehingga merasa puas dengan pelayanan terbaik yang diberikan, bahkan ketika ada saran atau kritikan dari beberapa pelanggan atau calon jamaah haji $\mathrm{KBIH}$ Maqdis selalu berevaluasi setiap harinya dengan ketua KBIH agar segala masalah mengenai pelayanan yang dikeluhkan dapat diperbaiki kedepannya. Ibu Hj. Erna Supartina menyatakan bahwa:

"Untuk melakukan evaluasi serta perbaikan-perbaikan yang dilakukan secara berkala dapat dilakukan dengan mengadakakan survei kepada pelanggan untuk mendapatkan feedback dari pelanggan maksudnya dengan cara berfokus pada hal-hal yang paling penting. Mengetahui rasa empati atau kepedulian terhadap calon jamaah atau pelanggan untuk mengukur tingkat kemampuan suatu lembaga dalam kehandalan melayani pelanggan" (Wawancara pada hari Senin, 28 Mei 2018).

Untuk memperbaiki kualitas pelayanan dapat dilakukan dengan cara memberikan standar pelayanan yang jelas kepada karyawan/staf KBIH Maqdis melatih karyawan agar lebih bertanggung jawab, cepat tanggap, dan memiliki etos yang lebih tinggi.

Kualitas kegiatan evaluasi cukup baik maka data yang dihasilkan dapat digunakan untuk mengambil keputusan mengenai peserta didik dan untuk penyempurnaan kurikulum. Sebaliknya jika evaluasi rendah mutunya, akan menyesatkan para pengambil keputusan atau kebijakan. Hal ini berarti bahwa evaluasi bertujuan untuk memperbaiki proses belajar siswa serta dapat memberi umpan balik yang dapat dipergunakan sebagai dasar untuk perencanaan di masa yang akan datang (Umar, 1991:22). 
Gambaran tentang baiknya suatu alat ukur tercermin pada karakteristik dari perangkat soal itu sendiri. Karakteristik adalah ciri-ciri yang melekat atau dimiliki oleh suatu perangkat soal yaitu validitas, reliabilitas, tingkat kesukaran, dan daya beda. (Masrun, 1978: 30).

\section{PENUTUP}

Berdasarkan hasil dari penelitian yang diperoleh penulis mengenai strategi dalam meningkatkan pelayanan prima kepada calon jamaah haji, maka akhirnya dapat diambil kesimpulan bahwa: Pertama, Konsep dalam upaya meningkatkan pelayanan prima terhadap calon jamaah haji maka $\mathrm{KBIH}$ Maqdis sangat memperhatikan dalam memberikan pelayanan kepada jamaah. Para karyawan KBIH Maqdis bertanggungjawab dalam memperhatikan jamaah dalam pelaksanaan agar dapat berjalan dengan aman, tertib, dan nyaman. Kemampuan para karyawan KBIH Maqdis juga sudah teruji dengan baik contohnya pembimbing ibadah haji yang sudah teruji dan berkualitas.

Kedua, implementasi KBIH Maqdis melakukan pelayanan terhadap calon jamaah haji dari mulai persiapan sampai kepulangan haji. KBIH Maqdis melaksanakan bimbingan manasik berupa ceramah dan diskusi, selama di Tanah Suci yang dilaksanakan di pondokan maupun di Masjid dalam program pemantapan mengenai materi manasik haji dan masalah-masalah lain seputar haji. selain itu juga dikaji masalah-masalah keagamaan menyangkut masalah aqidah, syariah, muamalah dan akhlak. dengan program tersebut diharapkan para jamaah dapat memiliki kemantapan dalam melaksanakan ibadah haji dan diharapkan mencapai haji yang mabrur. Ketua KBIH memberikan pelatihan dan pendidikan secara berkala terhadap karyawannya dan selalu memantau perkembangan dari pembimbing haji KBIH Maqdis dengan memperhatikan sertifikasi haji bagi pembimbingnya

Ketiga, evaluasi strategi pelayanan yang dilakukan oleh KBIH Maqdis sudah termasuk kepada excellent service karena dapat memuaskan semua pelanggannya. KBIH Maqdis ini memperoleh kepuasan tersendiri dari hasil pelayanan yang membuat para pelanggan atau calon jamaah haji itu merasakan kenyamanan, tanggung jawab, profesionalitas, dan pertumbuhan kepercayaan terhadap pelanggan.

Pelayanan yang diberikan oleh KBIH Maqdis ini sudah mengarah kepada yang namanya pelayanan prima. hal ini dapat terlihat dari terselenggaranya program yang dilaksanakan. walaupun demikian penulis memberikan saran kepada $\mathrm{KBIH}$ Maqdis yang sekiranya dapat digunakan sebagai bahan perbandingan dan pertimbangan dalam memberikan pelayanan kepada calon jamaah haji, yaitu dari segi manajemen pelayanan prima lebih komprehensif karena penulis merasa belum sempurna dan masih banyak kekurangan dalam proses penelitian ini. selain itu lebih di tingkatkan lagi pelayanan program di tanah suci dan di tanah air, 
misalnya membuat program bimbingan manasik kubro yakni simulasi haji secara keseluruhan yang di design sedemikian rupa menyerupai kegiatan ibadah haji yang sesungguhnya.

Perlu diketahui juga bahwa setiap lembaga butuh untuk memahami pelangannya terutama kebutuhan, keinginan pelanggan secara personal agar para pelanggan merasakan kepuasan atas pelayanan yang diberikan oleh KBIH. KBIH Maqdis juga selain memiliki KBIH juga memiliki Pesantren Tahfidz Qur'an sehingga masih terbuka lahan bagi peneliti selanjutnya. Saran tambahan untuk peneliti selanjutnya, semoga menjadi bahan rujukan dalam penelitiannya, supaya penelitian selanjutnya lebih sempurna lagi dari penelitian ini.

\section{DAFTAR PUSTAKA}

Academic Journal for Homiletic Studies. 5(15) 902

Andrews. Kenneth. r. (1985). Konsep Strategi Perusahaan. Surabaya: Erlangga. Aziz . (2007). Metode Penelitian dan Teknik Analisis Data. Jakarta: Salemba Medika

Dahlan, A.A. dkk (1997). Ensiklopedi Hukum Islam, Jilid 4, Jakarta: Ikhtiar Baru van Hoeve

Daryanto. (2014). Pendekatan Pembelajaran Saintifik Kurikulum 2013. Yogyakarta: Penerbit Gava Media.

Fandy, T. \& Gregorius, C. (2011). Service, Quality and Satisfaction, ed. 3. Yogyakarta: Andi.

Hunger, J. D. \& Wheelen, T. L. (2003). Manajemen Strategis. Yogyakarta: Andi.

Kusnawan, A. (2010). Perencanaan Pendidikan Tinggi Islam. dalam Ilmu Dakwah:

Masrun. (1978). Pengukuran dalam pendidikan. Yogyakarta: Fakultas Psikologi UniversitasGadjah Mada Yogyakarta.

Rasyid, S. (1976) Fiqh Islam, Jakarta: al-Thahiriyah

Sumayang, L. (2003). Dasar-dasar Manajemen Produksi dan Operasi. Jakarta: Penerbit Salemba Empat.

Umar, J. (1991). Pengantar Penilaian Pendidikan (Makalah). Jakarta: Pusisjian, Balitbang, Depdikbud 
N.Oktaviani, A.Rahman dan Herman 